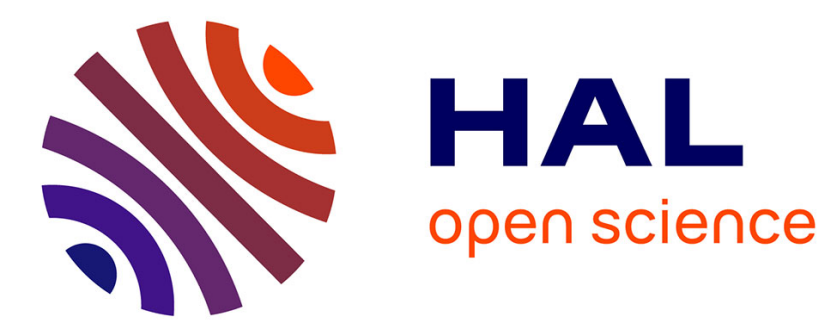

\title{
Portable microwave assisted extraction: An original concept for green analytical chemistry.
}

Sandrine Perino, Emmanuel Petitcolas, Miguel de La Guardia, Farid Chemat

\section{To cite this version:}

Sandrine Perino, Emmanuel Petitcolas, Miguel de La Guardia, Farid Chemat. Portable microwave assisted extraction: An original concept for green analytical chemistry.. Journal of Planar Chromatography, 2013, 1315, pp.200-203. 10.1016/j.chroma.2013.09.053 . hal-01328735

\section{HAL Id: hal-01328735 \\ https://hal.science/hal-01328735}

Submitted on 28 May 2020

HAL is a multi-disciplinary open access archive for the deposit and dissemination of scientific research documents, whether they are published or not. The documents may come from teaching and research institutions in France or abroad, or from public or private research centers.
L'archive ouverte pluridisciplinaire HAL, est destinée au dépôt et à la diffusion de documents scientifiques de niveau recherche, publiés ou non, émanant des établissements d'enseignement et de recherche français ou étrangers, des laboratoires publics ou privés. 


\title{
Portable microwave assisted extraction: An original concept for green analytical chemistry
}

\author{
Sandrine Perino ${ }^{\mathrm{a}, *}$, Emmanuel Petitcolas $^{\mathrm{a}}$, Miguel de la Guardia ${ }^{\mathrm{b}}$, Farid Chemat ${ }^{\mathrm{a}}$ \\ a Université d'Avignon et des Pays de Vaucluse, INRA, UMR 408, F-84000 Avignon, France \\ ${ }^{\mathrm{b}}$ Department of Analytical Chemistry, Research Building, University of Valencia, 50th Dr. Moliner St., E-46100 Burjassot, Valencia, Spain
}

Keywords:

Portable microwave assisted extraction

Miniaturization

Green analytical chemistry

Extraction

Essential oil

\begin{abstract}
A B S T R A C T
This paper describes a portable microwave assisted extraction apparatus (PMAE) for extraction of bioactive compounds especially essential oils and aromas directly in a crop or in a forest. The developed procedure, based on the concept of green analytical chemistry, is appropriate to obtain direct in-field information about the level of essential oils in natural samples and to illustrate green chemical lesson and research. The efficiency of this experiment was validated for the extraction of essential oil of rosemary directly in a crop and allows obtaining a quantitative information on the content of essential oil, which was similar to that obtained by conventional methods in the laboratory.
\end{abstract}

\section{Introduction}

Current trends in Green Analytical Chemistry are the development of portable instrumentation as an alternative to move the samples to the laboratory and thus, nowadays there are several available instruments to do it as, infrared instruments, energy dispersion X-ray fluorescence systems, portable gas chromatograph [1] or capillary electrophoresis [2]. A portable instrument can provide instant in-field results without the need to wait for the transport of collected samples from the forest to the laboratory. These past years, there is the development of portable sample preparation apparatus, which can help to do the in-field extraction, sample preparation, analysis and data evaluation. In parallel, a portable instrument is defined as "easily" movable, convenient for carrying, and capable of being transferred or adapted in altered circumstances [3].

Miniaturization (down scaling) is an important factor of modern society reflected strongly in science and technology [4] including medicine, chemistry, environment, food safety, etc. [5]. Miniaturization of a procedure can be achieved simply by reducing dimensions of the systems used in earlier approaches or by developing completely new set-ups or techniques. When compared to conventional systems, miniature systems can perform similar

\footnotetext{
* Corresponding author. Tel.: +33 04901444 26; fax: +33 0490144441. E-mail addresses: sandrine.perino@univ-avignon.fr, sandrine.issartier@univ-avignon.fr, sandrine.issartier@yahoo.fr (S. Perino).
}

methods with remarkably reduced consumption of plant matrix and solvents, size and power requirement, system cost and meanwhile faster analysis time and massively parallel analysis capability. It is an attractive method for application requiring on-field rapid assay [6,7].

From the aforementioned perspective, the idea has been to develop a portable microwave assisted extraction (PMAE) which can be used directly in the crop or the forest. Given its reduced size, this microwave technique requires a small amount of sample in a small glassware system which is designed as a miniature alembic to be placed inside a microwave oven. It was a challenge to develop a miniature alembic, suitable to provide a fast extraction of essential oils from the fresh samples and to collect the extract by using a Vigreux's column as an air-cooled condenser, suitable also to be placed inside the microwave oven. In this way, the PMAE apparatus can provide information about the actual state of the fresh samples and their essential oil content. This procedure is also appropriate for teaching laboratory, does not require any special microwave equipment. The experiment developed, additionally than to provide a fast information on real samples, allows the students to learn extraction, chromatographic and spectroscopic analysis skills, and is a dramatic visual example of rapid, sustainable and green extraction of natural products, suitable to be introduced to commercially successful, sustainable and green chemical processing with microwave energy.

Here, were reported for the first time the potential of portable PMAE coupled with a battery for the extraction of essential oil from rosemary directly in a crop or forest. The miniature glass system, 
(a)

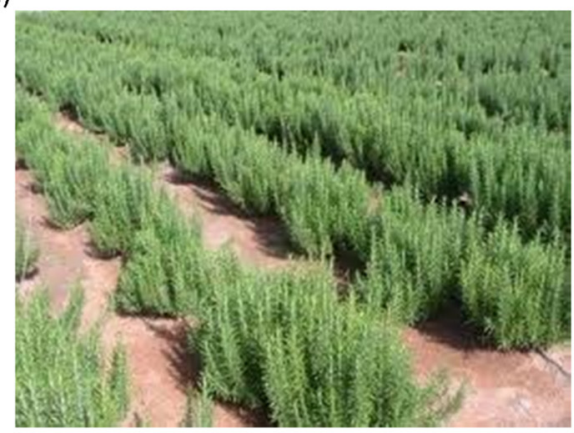

(c)

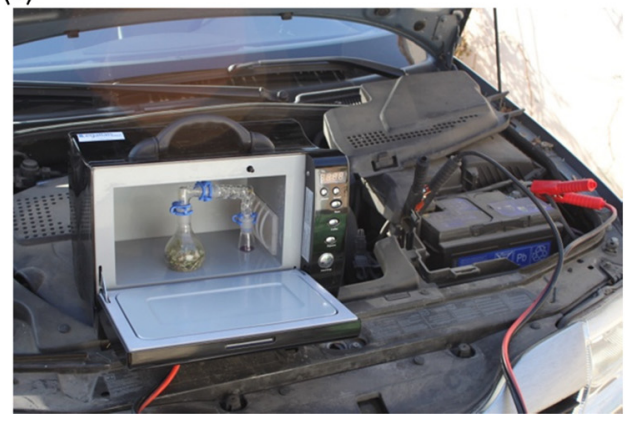

(b)

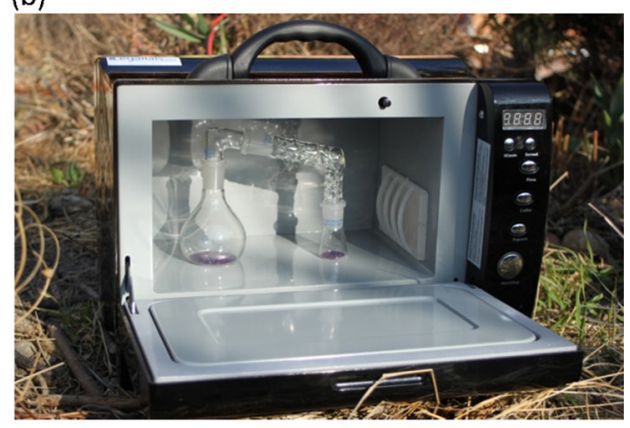

(d)

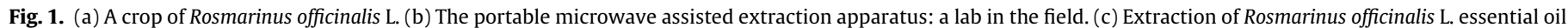
with the PMAE apparatus connected to the battery. (d) Essential oil and water in situ obtained with PMAE apparatus.

equipped with a Vigreux's column, was designed to illustrate the extraction phenomenon of essential oil in a rosemary's field. In this paper, the essential oil from rosemary obtained by PMAE has been compared with that obtained by conventional hydrodistillation (HD) in the lab, being samples analyzed by gas chromatography and mass spectrometry (GC-MS).

\section{Materials and methods}

\subsection{Plant material}

Rosemary (Rosmarinus officinalis L.) was collected in the south of France, in Avignon. Only fresh plant material was employed in all extractions. The initial moisture of leaves was verified in the laboratory as $59.8 \%$.

\subsection{Extraction methods}

Portable microwave assisted extraction (PMAE) apparatus consists of a portable microwave oven Nicole Microwave, Reimo that works on a car's battery (12 V). A miniature alembic employed for microwave assisted extraction is illustrated in Fig. 1. $30 \mathrm{~g}$ of fresh rosemary were weighed into the $100 \mathrm{~mL}$ Erlenmeyer flask with ground socket. Then, a Vigreux's column as an air-cooled condenser followed by an Erlenmeyer flask drilled (at atmospheric pressure) to collect the distillate, were adapted to the socket. The glass system was put into the microwave oven and heated for $15 \mathrm{~min}$ without added any solvent or water, using a fixed power of $100 \mathrm{~W}$. The essential oil layer was carefully transferred with a Pasteur pipette to a test tube. The oil was dried over anhydrous sodium sulphate, was weighed with a portable balance before being stored prior to analysis.

Conventional hydrodistillation [8] has been achieved according to the European Pharmacopoeia. $500 \mathrm{~g}$ of fresh rosemary were extracted with $2 \mathrm{~L}$ of water for $3 \mathrm{~h}$ in a conventional apparatus (until no more essential was obtained). The essential oil was collected, dried under anhydrous sodium sulphate and stored until to be analyzed.

\subsection{Analysis of essential oils}

Gas chromatography (GC) analysis was carried out using an Agilent 6850 gas chromatograph equipped with a flame ionization detector (FID), under the following operation conditions: vector gas, helium; injector and detector temperatures, $250^{\circ} \mathrm{C}$; injected volume, $1 \mu \mathrm{L}$; split ration 1/100; an HP5MS ${ }^{\mathrm{TM}}$ ( $30 \mathrm{~m} \times 0.25 \mathrm{~mm}$ I.D), with a film thickness $0.25 \mu \mathrm{m}$; a constant flow of $0.3 \mathrm{~mL} / \mathrm{min}$. Additionally, a Carbowax ${ }^{\mathrm{TM}}$ poly(ethylene glycol) $(60 \mathrm{~m} \times 0.20 \mathrm{~mm}$ I.D) column with a film thickness of $0.25 \mu \mathrm{m}$, was used. The oven temperature programme was $40^{\circ} \mathrm{C}$ for $8 \mathrm{~min}$ increased at $2{ }^{\circ} \mathrm{C} / \mathrm{min}$ to $250^{\circ} \mathrm{C}$ and held at $250^{\circ} \mathrm{C}$ for $30 \mathrm{~min}$. Gas chromatography mass spectrometry (GC-MS) analysis was carried out using an Agilent $6890 \mathrm{~N}$ coupled to an Agilent 5973 MS. Samples were analyzed using a fused-silica capillary column HP5MS ${ }^{\mathrm{TM}}(50 \mathrm{~m} \times 0.20 \mathrm{~mm}$ I.D., film thickness $0.50 \mu \mathrm{m}$ ) and Carbowax ${ }^{\mathrm{TM}}$ poly(ethylene glycol) $(60 \mathrm{~m} \times 0.20 \mathrm{~mm}$ I.D., film thickness $0.25 \mu \mathrm{m})$. Carrier gas, helium; injector and detector temperatures, $250^{\circ} \mathrm{C}$; injected volume, $1 \mathrm{~mL} / \mathrm{min}$; split ratio; the oven temperature programme was $40^{\circ} \mathrm{C}$ for $8 \mathrm{~min}$ increased at $2^{\circ} \mathrm{C} / \mathrm{min}$ to $250^{\circ} \mathrm{C}$ and held at $250^{\circ} \mathrm{C}$ for $30 \mathrm{~min}$; ionization energy, $70 \mathrm{eV}$; electron ionization mass spectra were acquired over the mass range $35-400 \mathrm{u}$. Identification of the components was based on computer matching against commercial libraries (Wiley, MassFinder 2.1 Library, NIST98), laboratory mass spectra libraries built up from pure substances, and MS literature data combined with comparison of GC retention indices (RI) on apolar and polar column. RIs were calculated with the help of a series of linear alkanes $\mathrm{C}_{6}-\mathrm{C}_{26}$ on apolar and polar columns (HP5MS $^{\mathrm{TM}}$ and Carbowax ${ }^{\mathrm{TM}}$ ). Compounds available in the laboratory were confirmed by external standard compound co-injection [9-12].

\section{Results and discussion}

\subsection{Extraction time, energy and environment impact}

PMAE procedure was finished after $30 \mathrm{~min}$ to obtain $3 \mathrm{~mL}$ of rosemary's essential oil compared to $3 \mathrm{~h}$ with conventional 
Version définitive du manuscrit publiée dans / Final version of the manuscript published in :

Journal of Chromatography A (2013), Vol. 1315, p. 200-203, DOI: 10.1016/j.chroma.2013.09.053

Journal home page: www.elsevier.com/locate/chroma

hydrodistillation apparatus and the essential oil yield was determined directly in the field with a portable balance.

PMAE experiment can be performed directly in a crop with a portable microwave oven connected to a battery. It is not necessary to collect the plant material in a crop or forest and take them in a no stabilized state during hours to go to the laboratory and then extract rosemary's essential oil with a Clevenger apparatus which needs to heat and boil $2 \mathrm{~L}$ of water with rosemary for several hours. The reduced cost of this green extraction is clearly advantageous for the PMAE method in terms of energy and environment impacts. The energy required to perform the two extraction methods are respectively $2 \mathrm{kWh}$ for $\mathrm{HD}$, and $0.1 \mathrm{kWh}$ for PMAE. The power consumption has been determined with a Wattmeter at the microwave generator entrance and the electrical heater power supply. Regarding environmental impact, the calculated quantity of carbon dioxide rejected in the atmosphere is much higher with conventional distillation $(1600 \mathrm{~g})$ than with portable microwave $(80 \mathrm{~g})$. These calculations have been made according to the literature considering that recovering $1 \mathrm{kWh}$ from coal or fuel combustion is associated with $800 \mathrm{~g}$ of $\mathrm{CO}_{2}$ being rejected in the atmosphere. The life cycle analysis (LCA) has not been applied for transportation and the apparatus used, which will dramatically enhance the positive impact of using PMAE.

\subsection{Composition of essential oil}

The chemical composition of rosemary essential oils varies and depends on locality, the climatic conditions and harvesting seasons. In our study, rosemary leaves were obtained from a crop in Avignon, France (august harvest). The oils obtained from each experiment were very similar in appearance, pale colour and fragrance. The composition of the essential oils obtained by HD and PMAE methods are given in Table 1 . A total of 25 compounds (in agreement with the literature) were identified in essential oils extracted from the same samples using the two techniques. The essential oil of rosemary leaves isolated either by PMAE or HD contains the same dominant components such as $\alpha$-pinene, camphor, verbenone and camphene. The monoterpene hydrocarbons are present in almost equivalent amounts in the HD and PMAE essential oils and $\alpha$-pinene, is the main abundant component in the essential oil extracted from rosemary with equivalent relative amounts for both extraction methods: $46.3 \%$ and $46.5 \%$, respectively for PMAE and HD. Camphor was the main oxygenated component in the essential oil isolated from rosemary leaves but the relative amounts are not differed for the two isolation methods. It is the most abundant oxygenated component of the essential oil 7.9\% for PMAE whereas the HD oil contains $7.8 \%$.

\subsection{Safety consideration}

This green microwave extraction method is totally safe even for nonhighly educated operators, college, high school and academia laboratories. We only use conventional domestic microwave oven "without any modification" as specified by manufacturer. The glassware even Vigreux column is simple to use, and do not create any

Table 1

Chemical composition of Rosmarinus officinalis L. essential oils obtained by portable microwave assisted extraction apparatus (PMAE) and hydrodistillation (HD).

\begin{tabular}{|c|c|c|c|c|c|}
\hline No. & Compounds ${ }^{\mathrm{a}}$ & $\mathrm{HD}(\%)$ & PMAE (\%) & $\mathrm{RI}^{\mathrm{b}}$ & $\mathrm{RI}^{\mathrm{c}}$ \\
\hline & Monoterpene hydrocarbons & 70.1 & 70 & & \\
\hline 1 & Tricyclene $^{\mathrm{d}}$ & 0.2 & 0.2 & 921 & 1011 \\
\hline 2 & $\alpha$-Pinene ${ }^{\mathrm{d}}$ & 46.5 & 46.3 & 936 & 1023 \\
\hline 3 & Camphene $^{\mathrm{d}}$ & 5.9 & 6.0 & 951 & 1103 \\
\hline 4 & Verbenene & 0.9 & 1.1 & 955 & 1121 \\
\hline 5 & $\beta$-Pinene ${ }^{\mathrm{d}}$ & 2.6 & 2.5 & 980 & 1109 \\
\hline 6 & Myrcene $^{\mathrm{d}}$ & 1.9 & 1.8 & 995 & 1149 \\
\hline 7 & $\alpha$-Terpinene ${ }^{\mathrm{d}}$ & 0.8 & 0.8 & 1020 & 1083 \\
\hline 8 & para-Cymene $^{\mathrm{d}}$ & 1.3 & 1.3 & 1025 & 1250 \\
\hline 9 & Limonene $^{\mathrm{d}}$ & 5.4 & 5.4 & 1030 & 1206 \\
\hline 10 & $\gamma$-Terpinene ${ }^{\mathrm{d}}$ & 3.0 & 3.0 & 1052 & 1251 \\
\hline \multirow[t]{2}{*}{11} & Terpinolene $^{\mathrm{d}}$ & 1.6 & 1.6 & 1092 & 1287 \\
\hline & Oxygenated monoterpenes & 24.4 & 24.9 & & \\
\hline 12 & Linalool $^{\mathrm{d}}$ & 2.3 & 2.3 & 1106 & 1538 \\
\hline 13 & $\alpha$-Campholenal & 1.2 & 1.3 & 1122 & 1471 \\
\hline 14 & Camphor $^{\mathrm{d}}$ & 7.8 & 7.9 & 1149 & 1514 \\
\hline 15 & Pinocarvone $^{\mathrm{d}}$ & 1.3 & 1.4 & 1160 & 1548 \\
\hline 16 & Borneol $^{\mathrm{d}}$ & 2.5 & 2.6 & 1173 & 1679 \\
\hline 17 & Terpin-4-ol $^{\mathrm{d}}$ & 2.1 & 2.1 & 1184 & 1590 \\
\hline 18 & $\alpha$-Terpineol ${ }^{\mathrm{d}}$ & 0.7 & 0.7 & 1198 & 1677 \\
\hline \multirow[t]{2}{*}{19} & Verbenone $^{\mathrm{d}}$ & 6.5 & 6.6 & 1207 & 1696 \\
\hline & Sesquiterpene hydrocarbons & 1.3 & 1.0 & & \\
\hline 20 & E-caryophyllene & 0.9 & 0.8 & 1425 & 1470 \\
\hline \multirow[t]{2}{*}{21} & $\beta$-Bisabolene ${ }^{\mathrm{d}}$ & 0.4 & 0.2 & 1508 & 1714 \\
\hline & Oxygenated sesquiterpenes & 0.3 & 0.3 & & \\
\hline 22 & Caryophyllene oxide $^{\mathrm{d}}$ & 0.1 & 0.1 & 1570 & 1977 \\
\hline \multirow[t]{2}{*}{23} & $\alpha$-Bisabolol ${ }^{\mathrm{d}}$ & 0.2 & 0.2 & 1684 & 2022 \\
\hline & Other oxygenated compounds & 0.9 & 1.0 & & \\
\hline 24 & Bornyl acetate & 0.8 & 0.9 & 1263 & 1579 \\
\hline 25 & Methyl eugenol & 0.1 & 0.1 & 1397 & 2032 \\
\hline Extraction time (min.) & 180 & 15 & & & \\
\hline Yield (\%) & 0.57 & 0.2 & & & \\
\hline Total oxygenated compounds & 25.6 & 26.2 & & & \\
\hline Total nonoxygenated compounds & 71.4 & 71.0 & & & \\
\hline
\end{tabular}

a Essential oil compounds sorted by chemical families and percentages calculated by GC-FID on non-polar HP5MS ${ }^{\mathrm{TM}}$ capillary column.

b Retention indices relative to $\mathrm{C}_{5}-\mathrm{C}_{28} \mathrm{n}$-alkanes calculated on non-polar HP5MS ${ }^{\mathrm{TM}}$ capillary column.

${ }^{c}$ Retention indices relative to $C_{5}-C_{28} n$-alkanes calculated on polar Carbowax ${ }^{\mathrm{TM}}$-PEG capillary column.

d Compounds know in the rosemary. 
Version définitive du manuscrit publiée dans / Final version of the manuscript published in :

Journal of Chromatography A (2013), Vol. 1315, p. 200-203, DOI: 10.1016/j.chroma.2013.09.053

Journal home page: www.elsevier.com/locate/chroma

problem of explosion, the PMAE being made at atmospheric pressure.

\section{Conclusion}

The aim of this paper was to explore the feasibility of a simple and low-cost portable microwave oven combined with a miniaturized alembic to extract natural products and especially essential oils directly in a crop or a forest. This original portable microwave assisted extraction provides a fast in-field information about the content of essential oils in fresh natural samples and offers important advantages over traditional hydrodistillation technique: it is quicker (less than $15 \mathrm{~min}$ ), effective and involves an environmentally friendly approach, with a reduced consume of energy and reagents. The PMAE apparatus can provide instant results on crop without the need to wait for the transport from the forest to the lab, the sample preparation, analysis and data evaluation. Moreover, PMAE could be employed as a laboratory exercise which easily teaches Green Analytical Chemistry. This PMAE apparatus allows obtaining essential oils similar to those obtained by conventional methods and successfully incorporates green analytical chemistry principles into the educational practical lessons.

\section{Acknowledgement}

The authors gratefully acknowledge Mr Bruno Zinck (company Legallais, Montpellier, France) for his help in the conception of the glass system. This scientific study was carried out as part of the Alcotra Eco-Extraction Transfrontalière project framework which brings together private and public-sector stakeholders (University of Avignon, European University of Fragrances \& Flavours, FranceAgriMer, University of Turin and Technogranda). We would also like to warmly thank our co-funding partners, i.e. the European Union (FEDER), the French and Italian governments, the Piedmont region as well as ADEME and the Conseil Régional Provence-Alpes-Côtes d'Azur through the Etat-RegionADEME framework programme. Their financial support has helped partners successfully achieve the project's scientific objectives.

\section{References}

[1] H. Lin, Q. Ye, C. Deng, X. Zhang, J. Chromatogr. A 1198-1199 (2008) 34

[2] S. Armenta, S. Garrigues, M. de la Guardia, Trends Anal. Chem. 27 (2008) 497.

[3] G. McMahon, Analytical Instrumentation: A Guide to Laboratory, Portable and Miniaturized Instruments, Wiley, Chichester, UK, 2007.

[4] J.A. Contreras, J.A. Murray, S.E. Tolley, J.L. Oliphant, H.D. Tolley, S.A. Lammert, E.D. Lee, D.W. Later, M.L. Lee, J. Am. Soc. Mass Spectrom. 19 (2008) 1425.

[5] S.J. Kim, K. Vengatajalabathy Gobi, R. Harada, D.R. Shankaran, N. Miura, Sens. Actuat. B 115 (2006) 349.

[6] M. Ryvolova, J. Preisler, D. Brabazon, M. Macka, Trends Anal. Chem. 29 (2010) 339.

[7] X. Sui, T. Liu, C. Ma, L. Yang, Y. Zu, L. Zhang, H. Wang, Food Chem. 131 (2012) 1399.

[8] Conseil de l'Europe, Pharmacopée Européenne, Maisonneuve S A. Editions, Sainte Ruffine, 1996.

[9] D. Joulain, W.A. König, The Atlas of Spectral Data of Sesquiterpene Hydrocarbons, 1st ed., E. B. Verlag, Hamburg, Germany, 1998.

[10] R.P. Adams, Identification of Essential Oil Components by Gas Chromatography/Mass Spectroscopy, Allured Publishing, Carol Stream, 1995.

[11] Boelens Aroma Chemical Information Service, Eso 2000 The Complete Database of Essential Oils, B.A.C.I.S., The Netherlands, 1999.

[12] N.W. Davies, J. Chromatogr. 503 (1990) 1 